\title{
TASMANIAN ABORIGINES AND DNA
}

by John C. Presser,
, Alan J. Redd and Mark Stoneking

(with one table)

\begin{abstract}
Presser, J. C.,
RedD, A. J. \& STONEKIng, M., 2002 (31:xii): Tasmanian Aborigines and ofthe Royal Society of Tasmania 136: 35-38. https://doi.org/10.26749/rstpp.136.35

ISSN 0080-4703. Forensic Consultant, GPO Box 1384, Hobart, Tasmania 7001, Australia QCP); Kimberley, Tasmania 7304 (AJD); Biotechnology Division, University of Arizona, Tucson, USA (AJR); Max Plank Institute for Evolutionary Anthropology, Molecular Anthropology Group, Leipzig, Germany (MS).
\end{abstract}

The hyper-variable control region (HV1 and HVII) of mitochondrial DNA (mtDNA) from .Tasmanians with an unbroken, direct Tasmanian Aboriginal maternal lineage were DNA sequenced. The lineage dates back to the early 1800 s, as evidenced by published family genealogies (Mollison 1978, Ryan 1981, Plomley 1966, 1971, 1987, 1990).

Of the five distinct mtDNA haplotypes discovered, V1 was found in living Tasmanian descendants traced back to a Port Phillip Aboriginal woman who lived with European sealers in Bass Strait. Haplotype T2 is two nucleotide transitions removed from 1/WD 2 of van Holst Pellekaan et al. 1998 and therefore related to this Australian mainland Aboriginal mtDNA haplotype.

Vestiges of Tasmanian maternal mtDNA haplotypes from before white settlement, passing down through up to eight generations, still survive in Tasmania. The Tasmanian Aboriginal people are related and relatable to mainland Aboriginal people.

Key Words: aborigine, Tasmania, Victoria, mitochondrial DNA, maternal lineage.

\section{BACKGROUND}

In May 1987, a female Tasmanian Aboriginal elder was sexually assaulted and stabbed to death in her home in Hobart. In the subsequent police investigation, forensic blood-marker screening using phosphoglucomutase typing by isoelectric focusing, followed by nuclear DNA testing by Cellmark Corporation (UK) of the semen component from the rape kit swabs led to the conviction of a young male relative. This was the first 'cold hit' DNA match in Australia and almost the only evidence against the perpetrator. After the criminal court appeals were over in 1990, the local Tasmanian Aboriginal community awarded the investigation team an inscribed plaque and written vote of thanks (The Mercury, Hobart 1990).

In order to strengthen a prosecution case based almost solely on novel nuclear DNA evidence, it was decided to investigate possible additional evidence from human mitochondrial DNA sequences. This line of investigation was not completed for this case and not used in trial evidence. However, in view of the forensic potential of mitochondrial DNA databases in cases of missing persons presenting as skeletal remains only and in trace evidence with no nuclear DNA material (such as 'fallen' human hair fibres), blood samples from this case and other cases were included in a Tasmanian mitochondrial DNA database project.

\section{MITOCHONDRIAL DNA}

Most of the DNA in human cells is contained within the 46 chromosomes in the nucleus. Mitochondria, which are subcellular organelles found outside the nucleus in the cytoplasm, contain an extra chromosomal genome separate and distinct from the nuclear genome. Human mtDNA differs from nuclear DNA in the following ways:

\footnotetext{
* Aboriginal Elder, descendant of Mannalargenna and Tanleeboneyer.
}

1. It is a very much smaller (about 16,500 bases long), closed (circular) genome more similar to that of bacteria than to the fragile, extended, linear arrangement of nuclear chromosomes of multicellular organisms.

2. mtDNA is present in high copy numbers per cell: on average, approximately one thousand times the nuclear number.

3. mtDNA is compact, coding only for two ribesomal RNAs, 22 transfer RNAs, 13 proteins and a non-coding region about 1100 bp long, called the "displacement loop" (D-loop) or "control region". The hyper-variable D-loop region includes HV1 16024-16383 and HVII 57-372. The primers used in this study are those used by Vigilant et al. (1989) amplifying from 15996 to 16401 (HVI) and from 29 to 408 (HVII).

4. Human mtDNA has two separate origins of replication. The origin of $\mathrm{H}$-strand or leading strand replication $(\mathrm{OH})$ is located in the displacement loop region, while the origin of $\mathrm{L}$-strand or lagging strand replication $(\mathrm{OL})$ is within a cluster of five transfer RNA genes. Replication of mtDNA is initiated at $\mathrm{OH}$. It requires both RNA synthesis and subsequent processing events to prime DNA synthesis. When the H-strand has elongated to two-thirds of its total length, OL is exposed and sponsors initiation of L-strand replication.

5. The displacement-loop (D-loop) region is the control site for both transcription and replication of mtDNA. Each strand of mtDNA contains a major dedicated promoter (the $\mathrm{H}$-strand promoter) and the L-strand promoter. The L-strand promoter serves two purposes. It is the promoter for one protein and eight transfer RNA genes, and transcripts initiated here are used as primers for $\mathrm{H}$-strand $\mathrm{mtDNA}$ replication. The transitions from RNA to DNA synthesis occur over a region of short, conserved sequences termed "conserved sequence blocks" (CSB I-III). There are no introns in mtDNA (Clayton 1992).

6. mtDNA is inherited maternally. Apart from mutational changes, it is identical for siblings and all their maternal relatives. This monoclonal nature simplifies DNA sequencing. Until recently, mtDNA was thought not to 
undergo recombination and therefore to be inherited only in the maternal line (Gyllensten et al. 1991). However, this has recently been a subject of debate (Awadella et al. 1999, Kumar et al. 2000, Parson \& Irwin 2000, Elson et al. 2001).

Heteroplasmy (Gill et al. 1995, Allen et al. 1997) is a condition where more than one single mtDNA sequence is observed in an individual. Generally, heteroplasmic mtDNA sequences differ at a single nucleotide site within an individual. Length variation has been observed in the HV1 region (Bendell \& Sykes 1995) and in the HVII region (Stewart et al. 2001). Heteroplasmy is constant in the control region over the life of the individual (Tully et al. 2000, Lagerstrom-Fermer et al. 2001).

7. The mutation rate for mtDNA is five to ten times that of single-copy nuclear genes, due to the low fidelity of the specific mtDNA polymerase and the apparent lack of mtDNA repair mechanisms (Wolstenholme \& Jeon 1992).

\section{MATERIALS AND METHODS}

Mitochondrial DNA was isolated from whole blood samples dried onto sterile cotton cloth. It was extracted with the IsoQuick kit (ORCA Research Inc Bothell, WA 98021 USA CN MXT-020-100) and sequenced for both HV1 and HVII regions. DNA sequencing of PCR products with biotinylated primers was performed as described by Redd $e t$ al. (1995).

\section{RESULTS AND DISCUSSION}

The alignment of the DNA sequences in table 1 is according to the revised CRS of Andrews et al. (2000). The Human Genome Project could be considered to have begun with the publication of the complete sequence of human mitochondrial DNA (Anderson et al. 1981). However, the original mtDNA reference sequence has been shown to contain both errors and rare polymorphisms (Andrews et al. 2000). As table 1 relates to comparisons within indigenous Australia, the common European, but not global, sites HVII 073 and HVII 263 have been rendered in half-tone.

Using published Tasmanian Aboriginal lineage data (Mollison et al. 1978, Ryan 1981, Plomley 1966, 1971, 1987, 1990) and comparisons with published studies of Australian mainland Aboriginal mtDNA (Van Holst Pellekaan et al. 1998, Redd et al. 1999, Huoponen et al. 2001), 13 unusual control-region mtDNA sequences were found in the 19 individuals tested. Six were assigned to European descent. The remaining 13 fell into five distinct groups: T1A, T1B, T2, T3 and V1 (see table 1).

Haplotype V1 was found in living Tasmanian descendants of an abducted Port Phillip (Victorian) Aboriginal woman "Granny Betty". V1 is similar to 23/Western Desert 12 of the Australian mainland Aboriginal mtDNA HVI sequences listed in van Holst Pellekaan et al. 1998 and for HVII as well (van Holst Pellekaan 2002, pers. comm.).

Haplotype T1A and related sequence T1B are the most remote of the sequences found when compared to van Holst Pellekaan et al. (1998) for HVI and HVII (van Holst Pellekaan 2002, pers. comm.).

Haplotype T2 is two nucleotide transitions different from 1/Western Desert 2 of van Holst Pellekaan et al.
(1998) for HV1 and matching for HVII (van Holst Pellekaan 2002, pers. comm.).

Haplotype T3 may be distantly related to V1.

The nucleotide cytosine or ' $C$ ' at position 146 in HVII may be an indicator of Tasmanian origin. It is found in $17 \%$ of the 47 HVII of mainland Aborigines (van Holst Pellekaan 2002, pers. comm.), but in all but one (T3) of the small sample of haplotypes from indigenous Tasmanians. Meyer et al. (1999) found that this position mutates six times faster than the rest of HVII, which suggests that many more indigenous Tasmanian direct-descent examples and also known pre-settlement samples need to be analysed to resolve this question.

The global human evolutionary comparisons of mtDNA sequences are now based on comparisons of the complete $\mathrm{mtDNA}$ sequence, with analysis of the longer coding region (Ingman et al. 2000). The hyper-variable regions of mtDNA HV1 and HVII mutate at a faster and more variable rate than the coding region, and so are less useful for global comparisons but are useful for comparisons with Australia or Sahul (Stoneking 2000).

A search for, and analysis of, the non-recombining DNA section of the male Y chromosome 21 (Redd et al. 2002) from non-interrupted paternal Tasmanian lineages should also throw light on the relationship between the Tasmanian and Australian indigenous peoples.

\section{ACKNOWLEDGEMENTS}

The authors thank Sergeant Rod Gillies of Tasmania Police for assistance in collecting the blood samples used for this study and the Hobart Aboriginal community for their understanding and support of the study.

\section{REFERENCES}

Allen, M., Engstrom, A., Meyers, S., Handt, O., Saldeen, T. von Haeseler, A., Paabo, S. \& Gyllensten, U., 1998: Mitochondrial sequencing of shed hairs and saliva on robbery caps; sensitivity and probabilities. Journal of Forensic Sciences 43: 453-464.

Anderson, S., Bankier, A.T., Barrell, B.G., De Bruijn, M.H.L., Coulson, A.R., Drouin, J. \& Eperon, I.C., 1981: Sequence and organisation of the human mitochondrial genome. Nature 290: 457-465.

Andrews, R.M., Kubacka, I., Chinnery, P.F., Lightowlers, R.N., Turnbull, D.M. \& Howell, N., 1999: Reanalysis and revision of the Cambridge reference sequence for human mitochondrial DNA. Nature Genetics 23: 147 152.

Awadella, P., Eyre-Walker, A. \& SMith, J.M., 1999: Linkage disequilibrium and recombination in hominid mitochondrial DNA. Science 286: 2524-2525.

BENDELl, K.E. \& SYKeS, B.C., 1995: Length heteroplasmy in the first hypervariable segment of the human mtDNA control region American Journal of Human Genetics 57: 248256.

Clayton, D.A., 1992: Transcription and replication of animal mitochondrial DNA. International Review Cytology 141: 217-232.

Elson, J.L., Andrews, R.M., Chinnery, P.F., Lightowlers, R.N., Turnbull, D.M. \& Howell, N., 2001: Analysis of European mtDNA's for recombination. American Journal of Human Genetics 68: 145-153. 
TABLE 1

Variable mtDNA nucleotide sites D-loop HVI and HVII; Tasmanian Aboriginal descent

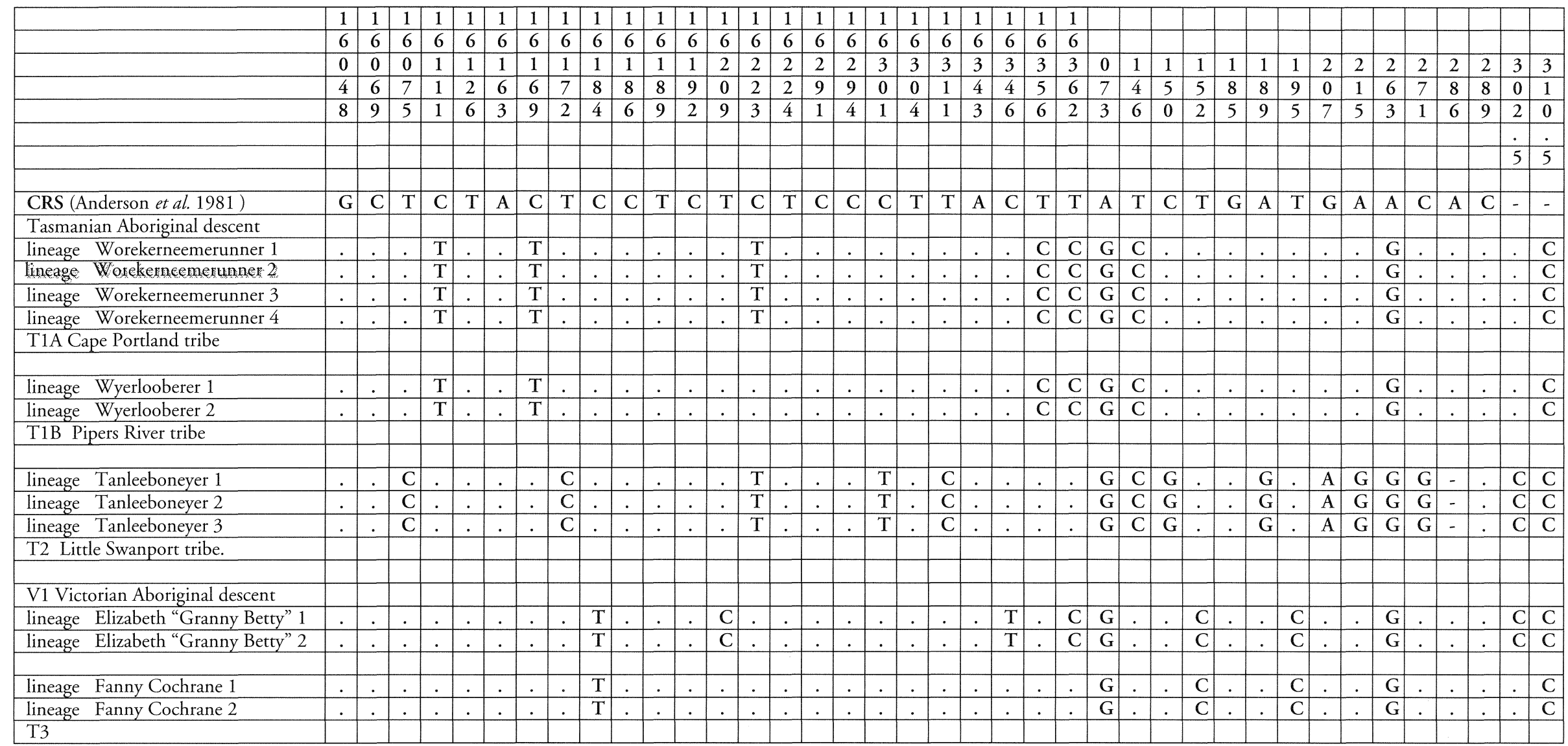


Gill, P., Ivanov, P.L., Kimpton, C., Piercy, R., Benson, N. \& Tully, G., 1994: Identification of the remains of the Romanov family by DNAS analysis. Nature Genetics 6: $130-135$.

GreenberG, J.H., 1971: The Indo-Pacific hypothesis. Current Trends in Linguistics 8: 807-871.

Gyllensten, U., Wharton, D., Josefsson, A. \& Wilson, A.C., 1991: Paternal inheritance of mitochondrial DNA in mice. Nature 352: 255-257.

Huouponen, K., Schurr, T. G., Chen, Y., \& Wallace, D.C., 2001: Mitochondrial DNA variation in an Aboriginal Australian population; evidence for genetic isolation and regional differentiation. Human Biology 62: 954-969.

Ingman, M., Kaesmann, H., PaAbo, S. \& Gyllensten, U., 2000: Mitochondrial genome variation and the origin of modern humans. Nature 408: 708-713.

Kumar, S., Hedrick, P., Dowling, T. \& Stoneking, M., 2000: Questioning evidence for recombination in human mitochondrial DNA. Science 288: 1931a.

Lagerstrom-Fermer, M., Olsson, C., Forsgren, L. \& Syvanen, A., 2001: Heteroplasmy of the human mtDNA control region remains constant during life. American Journal of Human Genetics 68: 1299-1301.

Meyer, S., Weiss, G. \& Von Haesler, A., 1999: Pattern of nucleotide substitution and rate heterogeneity in the hypervariable regions I and II of human mtDNA. Genetics 152: $1103-1110$.

Mollison, B.C. \& Everett, C., 1978: The Tasmanian Aborigines, vol. 1 A Synopsis of Data on Tasmanian Aborigines, vol. 2 A Chronology of Events Affecting Tasmanian Aboriginal People since Contact by Whites 1772-1976, vol. 3 The Genealogies. Department of Geography, University of Tasmania, Hobart.

PARSON, T.J. \& IRWIN, J.A., 2000: Questioning evidence for recombination in human mitochondrial DNA. Science 288: 1931a.

Plomley, N.B.J., 1966: Friendly Mission: the Tasmania Journals and Papers of George Augustus Robinson. Tasmanian Historical Research Association, Hobart.

Plomley, N.B.J., 1971: Friendly Mission: the Tasmania journals and papers of George Augustus Robinson. Papers and Proceedings of Tasmanian Historical Research Association 18: 5-32. Supplement.

Plomley, N.B.J., 1987: Weep in Silence: A History of the Flinders Island Aboriginal Settlement. Blubber Head Press, Hobart ISBN 0-908528-15-9.

Plomley, N.B.J. \& Henley, K.A., 1990: The sealers of Bass Strait and the Cape Barren Island community. Papers and Proceedings of Tasmanian Historical Research Association 37: 37-127.
Redd, A.J., Takezaki, N., Sherry, S.T., McGarvey, S.T., Sofro, A.S.M. \& STONEKING, M., 1995: Evolutionary history of the Coii/t-RNAlys intergenic 9 base pair deletion in human mitochondrial DNAs from the Pacific. Molecular Biology Evolution 12: 604-615.

Redd, A.J. \& Stoneking, M., 1999: Peopling of Sahul: mtDNA variation in Aboriginal Australian and Papua New Guinean populations. American Journal of Human Genetics 65: 808-828.

Redd, A.J., Roberts-Thompson, J., Karafet, T., Bamshad, M., Jorde, L.B., Naidu, J.M., Walsh, B. \& Hammer, M.F., 2002: Gene flow from the Indian Subcontinent to Australia: evidence from the Y chromosome. Current Biology 12: 673-677.

Ryan, L., 1981: The Aboriginal Tasmanians. University of Queensland Press, St Lucia. ISBN 0-7022-1544-9.

Stewart, J.E.B., Fisher, C.L., Aagahrd, P.J., Wilson, M.R., Isenberg, A.R., Polanskey, D., Pokorak, E., Dizinno, J.A. \& Budowle, B., 2001: Length variation in HV2 of the human mitochondrial DNA control region. Journal of Forensic Sciences 46: 862-870.

STONEKING, M., 2000: Hypervariable sites in the mtDNA control region are mutational hotspots. American Journal of Human Genetics 67: 1029-1032.

THE MERCURY, Hobart, 10 October 1990.

Tully, L.A., Parson,T.J, Steighner, R.J., Holland, M.M., Marino, M.A. \& Prenger, V.L., 2000: A sensitive denaturing gradient-gel electrophoresis assay reveals a high frequency of heteroplasmy in hypervariable region of the human mtDNA control region. American Journal of Human Genetics 67: 432-443.

Van Holst Pellekaan, S.M., Frommer, M., Sved, J.A. \& Boettcher, B., 1998: Mitochondrial control-region sequence variation in Aboriginal Australians. American Journal of Human Genetics 62: 435-449.

Vigiland, L., Pennington, R., Harpending, H., Kocher, T.D. \& WILSON, A.C., 1989: Mitochondrial DNA sequences in single hairs from a southern African population. Proceedings of the National Academy of Science 86: 9350 9354.

Wolstenholme, D.R. \& JeON, K.W., (Eds) 1992: Mitochondrial Genomes, vol. 141 in International Review of Cytology/ Survey of Cell Biology. Academic Press, San Diego, California. ISBN 0-12-364544-1.

(accepted 29 July 2002) 